\title{
Owner-manager when death do us part - roles of a widow in sudden succession in family firms
}

\author{
Hanna Almlöf \\ Department of Management and Engineering, Linköping University, \\ Linköping, Sweden and \\ Center for Family Enterprise and Ownership (CeFEO), \\ Jönköping International Business School, Jonköping, Sweden, and \\ Hans Sjögren \\ Department of Management and Engineering, Linköping University, \\ Linköping, Sweden and \\ Department of Marketing and Strategy, Stockholm School of Economics, \\ Stockholm, Sweden
}

\begin{abstract}
Purpose - This study sheds light on a hitherto understudied group in family business literature: widows. We explore the roles a widow may take following the unexpected death of her owner-manager spouse when she had no salient role in the business prior to the death.

Design/methodology/approach - We used a qualitative approach to research, to study inductively the roles considered and taken by three widows who unexpectedly succeeded as owners of Swedish privately held family firms. We conducted semi-structured interviews with widows and children in top management.

Findings - We construct a typology of four main roles a widow can take and analyse the underlying dimensions that they represent. We also analyse to which extent the choice of role widow can be explained by psychological ownership and double-loss theory. The typology can be used as a tool for family business owners and their advisors as the basis of an open and non-prejudiced discussion of the choices available to a widow. Originality/value - We have investigated the factors that influence a widow's decision whether to take over the business or not, as suggested in previous research by, for example, Martinez et al. (2009). We explore the roles a widow can consider and adopt. The study advances our understanding of how businesses can remain as family firms also in the event of the unexpected death of an owner-manager (De Massis et al., 2008). We hereby contribute to the literature on sudden successions and on women in family businesses.
\end{abstract}

Keywords Family dynamics, Widow, Sudden succession, Sudden death, Psychological ownership, Doubleloss theory

Paper type Research paper

\section{Plain English summary}

What makes a widow take over the firm after the unexpected death of her spouse, when she had played no salient role in the business prior to the death? In this case study, we explore the roles considered and taken by widows to learn more about how to handle sudden successions in family firms. Our typology of roles can assist advisors who meet widows or widowers in family businesses.

C Hanna Almlöf and Hans Sjögren. Published by Emerald Publishing Limited. This article is published under the Creative Commons Attribution (CC BY 4.0) licence. Anyone may reproduce, distribute, translate and create derivative works of this article (for both commercial and non-commercial purposes), subject to full attribution to the original publication and authors. The full terms of this licence may be seen at http://creativecommons.org/licences/by/4.0/legalcode

This research was made possible through generous research grants from Marianne and Marcus Wallenberg Foundation; Jan Wallander and Tom Hedelius Foundation; and Tore Browaldh Foundation.

manager when death do us

part

Received 15 January 2021

Revised 19 March 2021

Accepted 14 April 2021 


\section{Introduction}

Succession is a key issue in the lifetime of a family-owned company, and is therefore a key topic for family business literature (see e.g. Litz et al., 2012). Succession planning is given high priority by family business advisors, often with the mantra that it is never too late to start planning. However, sometimes family dynamics causes unplanned or unprepared changes in ownership structures. The sudden death of the owner-manager, or the sudden diagnosis of a fatal illness, will force family members to face a situation befogged with emotions and requiring many tough decisions. The leading role in such tragedy might be played by the spouse of the owner-manager - the widow. If she had been an active co-owner of the business or held a managerial position in the firm prior to the death, she may be expected to continue the business. However, if her role in firm was not salient, her entry onto the family business stage might be unexpected.

Unexpected, premature loss of a founder or owner-manager is identified as a possible factor that may prevent intra-family succession despite such intentions (De Massis et al., 2008). This preventing factor can be overcome by an act of the widow. Some widows have successfully taken over a family business, and not only ensured that it survived the loss of the previous owner-manager, but also managed to include and engage the next generation. By studying such widows, we can learn more about how to handle sudden deaths and rushed successions in family firms.

Research in the field of family businesses that examines the role of women is sparse (Achtenhagen et al., 2017; Martinez-Jiménez, 2009). Scholars such as Fitzgerald and Muske (2002) and Ponthieu and Caudill (1993) have examined copreneurial couples. Poza and Messer (2001) have examined the role of a spouse, and emphasised her possible influence on succession and continuity. However, the literature on women and succession in family firms focuses on daughters, not spouses or widows (Campopiano et al., 2017). Hence, how the role of a spouse changes when she becomes a widow has not been studied. A decade ago, Martinez-Jiménez (2009) called for further research on the topic, and in particular, identification of the factors that cause a widow to decide to take over the business. Nevertheless, widows in family businesses still have attracted little attention in literature (Achtenhagen et al., 2017).

The widow may be viewed as a victim of the tragic events that led to her taking on ownership responsibility and becoming a business leader. However, viewing widows as helpless objects of other peoples' actions is a great mistake (Du Rietz, 2013; Cesaroni and Sentuti, 2014; Moring and Wall, 2017). If she had not become a widow, she would have continued to be the wife of a business owner. In contrast, as an independent businesswoman, she gains the opportunity to run an enterprise on her own (Antheaume and Robic, 2012).

In this study we have explored the roles of widows in family firms. Our research question was: What roles can a widow take in cases of sudden death or rushed succession due to sudden fatal illness of her owner-manager spouse, when she has played no salient role in the business prior to the death or illness? Through a qualitative approach to research, we have inductively studied the roles considered and taken by three widows who became owner-managers of Swedish privately held family firms. Based on their stories, we construct a typology of four main types of role that are available to widows, and analyse the underlying dimensions that these roles represent. We add to knowledge relating to family businesses and the roles of women in family firms by shedding light on a hitherto understudied group, i.e. widows. Further, we contribute to the knowledge on sudden deaths and sudden successions in family firms by developing a typology of main role-types considered or taken by widows, and analyse the underlying dimensions that these roles represent. Our typology may also assist advisors who meet widows or widowers in family businesses. 


\section{Literature review and theory}

Our study communicates with two streams of literature: sudden deaths or sudden successions in family firms, and spouses in family firms, or more particularly widows. The sudden death of CEOs has previously been studied in the context of listed firms. Several scholars (e.g. Johnson et al., 1985; Worrell and Davidson, 1987; Salas, 2010) have focused on the effect on stock price when a death is announced, and when a company publishes information about a successor. In general terms, if the former CEO was seen as a strong leader and vital to the company, the stock price tends to fall following news of the sudden death, and vice versa. Larcker and Tayan (2012) stress that the sudden death of a CEO can provide insights into both the quality of succession planning and the quality of corporate governance mechanisms in the firm. On the latter topic, both Borokhovich et al. (2006) and Nguyen and Nielsen (2010) point to the importance of independent directors in cases of sudden succession without apparent successor.

Sudden death in private family-owned businesses should give rise to many other interesting questions than its effect on firm value and the importance of independent directors. Generally, ownership succession and management succession are two different but tightly intertwined processes in family firms (Haag, 2012). Both types of succession can be planned for individually, but when the owner-manager dies suddenly, the two processes become one. Steier (2001) defines "sudden succession" as the process that occurs when unanticipated events such as death or illness require that another family member assume a management role at short notice. No succession planning is possible. A related situation is "rushed succession", in which the family is forced to make unanticipated changes in management, although a limited window for urgent planning and asset transfers is open. Steier's study on ways in which relational wealth is transferred, created and managed in family firms showed that sudden and rushed succession are two of four modes by which social capital can be transferred. On a similar topic, Barbera et al. (2018) studied entrepreneurial legacy. In their single case study, the legacy story of the sudden death of the grandfather, which forced an early succession to the third generation, still echoes in the family more than 50 years later.

Sudden death has also been dealt with from a legal perspective, emphasising the need of preparation of ownership changes, not only planning of management succession. Sund et al. (2010) pointed out that sudden events cannot be truly planned for, but the family and other close stakeholders can prepare to cope with the unexpected. It is essential to understand the national legal framework, including inheritance law, company law and tax law, when drawing up an emergency plan. It is also often necessary to adapt contracts, particularly if the business is co-owned. Sudden succession has received some attention in studies of family businesses, but more needs to be done. Eddleston et al. (2019), for example, suggest further research on how sickness or sudden death affects the willingness and ability to prepare for emergencies in family firms, and their effects on decision-making and risk-taking. We have examined an earlier situation, and studied the acute phase during which a widow is faced with the choice to keep the business or sell it.

The second stream of literature considered here is women in family business succession and female spouses. On a general note, Achtenhagen et al. (2017) and Martinez-Jiménez (2009) have shown that the role of women in family businesses has received little scholarly interest. Laffranchini and Hoy (2020, p. 153) have specifically highlighted the potential for case studies on the topics of gender and the roles of women in family firms. In a comprehensive literature review by Campopiano et al. (2017), the authors show that out of 16 identified articles on women and succession in family firms, all were concerned with daughters as successors, not spouses or widows. Primogeniture dominated in the ancient world, and this has given way to a world in which a widow or a daughter is just as likely to be the scion of a family business. The trend goes hand-in-hand with the stricter demands for formal education and experience mannerdeath do us

part 
that are inherent to the digital economy, in a world governed by meritocracy. Nevertheless, the history of family businesses shows clearly that blood is still thicker than water (Colli, 2003; Sjögren, 2018).

Ahrens et al. (2015) studied gender preferences in family firms and found that males are still the preferred choice for succession, and succession within the family is significantly more probable when the predecessor has a son. However, they concluded that sudden and unplanned successions that occur due to the illness or death of the predecessor decrease the probability that only family heirs will be viewed as potential successors. Humphreys (2013) investigated the succession process for daughters, and concluded that those who succeeded were those who were intrinsically motivated to take over the family business and had had a strong successor-incumbent relationship with their father. In the same direction, Overbeke et al. (2015) emphasise that a shared vision between fathers and daughters is central to daughter succession. Overbeke et al. (2013) have also found that most daughters only consider becoming a successor when critical events, such as the father's illness or an explicit call for help, motivate her to do so.

The likelihood to become successful as a female successor in a business firm seems to be related to the owner-manager's and family's perception of gendered learning strategies, according to a study of Chinese family-SMEs (Mustafa et al., 2019). While knowledge about growth and survival of the firm was deemed to be the exclusive domain of men, dealing with employees and administration were considered by the interviewees to be the domain of women. However, despite this gender bias, the female successor was able to adopt various learning strategies and acquire specific knowledge about the family-SME as a means to attain leadership legitimacy. Obviously, the expectation of business behaviour is governed by feminine and masculine stereotypes. A study of female-led creative businesses in the UK showed that the maintenance of "business owner" identity required the women to present themselves as systematic, logical and rational, rather than intuitive, in order to fit current societal stereotypes of how a business owner behaves, despite the importance of intuition and creativity to their businesses (Martin $e t$ al., 2019). In order to be accepted, they maintained multiple work identities. While occupying male stereotypes and avoiding the female realm of emotion at work, these women expressed femininity through an emphasis on the maternal, "being a good mother" as a desired ideal being embedded in both work as well as home practice.

For many employed women, the family business may function as a professional sanctuary. A study of 80 female entrepreneurs in Italy showed that family and kinship are prerequisites for women as business leaders (Rinaldi and Tagliazucchi, 2019). When a woman took control after a change of ownership or following the death of her husband, the circumstances forced her to reshape her role in the company. A Swedish study also showed that the family business constitutes a springboard for women who want to enter the business world - the glass ceiling for women tends to be higher in family businesses (Karlsson, 2020). It turned out that Swedish women were significantly more common in the top positions of family businesses than in other forms of Swedish non-listed companies.

While daughters as successors are the focus in the literature on women and succession in family firms, other female roles are often overlooked. However, Poza and Messer (2001), for example, studied the role of a spouse and emphasised her possible influence on succession and continuity in the family firm, while Ramadani et al. (2017) explored the succession decision-making process in women-owned small family businesses. Widows have only attracted limited interest, with two interesting exceptions by Moussaid et al. (2019) and Heinonen and Ljunggren (2018), see below. From a historical study of 80 "business widows" from the 17th century and onwards, it is clear that widows, as owner-managers, are not a homogeneous group (Sjögren, 2021). There are both older and younger women represented, with or without a previous professional career, and they are spread across a range of 
industries. Naturally, the operations they carry out differ depending on, for example, firm size, industry, number of employees and ownership structure.

\section{Double-loss theory and psychological ownership}

A French-Lebanese study looked at early widowhood, and interviewed fifteen widows who took over a family business between 2013 and 2018 (Moussaid et al., 2019). The authors built on a theory of mourning and introduced the concept of double loss in the context of family businesses. While she can do nothing about the loss of her husband, a widow can resist the loss of the family business. This is a clear driving force for widows who take on the responsibility. These stories of early widowhood also revealed that events took place with extreme urgency, which made it necessary to pass through the phases of mourning rapidly, and caused them to be less visible. Women who had unexpectedly lost their partner emphasised how important it is to quickly declare that they do not intend to sell the company, and will shoulder the responsibility that has arisen. Some even defended themselves against being called a "widow", because they believed that the word is negatively charged. One widow said: "His death was a disaster. I was there because I felt that if I did not hold on, he would die again, and I did not want to, I did not want to forget him, and I did not even want to be called a widow." (Moussaid et al., 2019, p. 103) Another widow said: "He must remain alive in us and in what he has built, every day, we do a little for that." (Moussaid et al., 2019, p. 104).

The effort to avoid double loss is also apparent in a study of Finnish family businesses, where the husbands had died unexpectedly and suddenly (Heinonen and Ljunggren, 2018). The authors examined three companies that had passed the first-generation stage, two of which belonged to large company groups with more than 250 employees. The widows had acted resolutely to avoid a catastrophe in the commercial activity, while at the same time experiencing grief. The women had improvised in a pragmatic way to make rational strategic decisions while managing their emotions, even though no plan for transition to the widow had been drawn up in advance. The care of the employees was one reason given to ensure that work resumed as soon as possible.

Research looking at the roles of widows in family firms suggests that a widow's choice to not sell the family business may be a way to avoid double loss. In family business literature, several scholars have called for further research into how to integrate family science, which draws from e.g. anthropology, sociology and psychology, into the field (Jaskiewicz and Dyer, 2017; Combs et al., 2020). We partly answer this call by analysing to what extent the doubleloss theory can explain the widow's choice of role.

The psychological ownership of organisations may provide another reason that a widow takes on the responsibility of a family business. Pierce et al. (2001) defined "psychological ownership" as a state of mind in which individuals feel as if the target of ownership (material or immaterial in nature), or a piece of it, is theirs. This state of mind can manifest itself in organisations. Pierce et al. suggested several reasons for psychological ownership. One reason is that it arises from the ability to influence or to exercise control over the organisation. Another reason is that the psychological owner is associated with the organisation and familiar with it. A third explanation is that the owner is self-invested, for example has invested time, ideas, skills and intellectual energy into the organisation. Psychological ownership has been used to study topics such as job satisfaction and the work attitudes of non-family members (Sieger et al., 2011; Bernhard and O'Driscoll, 2011; Ramos et al., 2014; Erdem and Atsan, 2015; Mustafa et al., 2020), non-family CEO's contribution to financial and non-financial goals (Huybrechts et al., 2013), stewardship behaviour of CEOs (Henssen et al., 2014) or top management team members (Lee et al., 2019; Broekaert et al., 2018), and as a determinant of entrepreneurial orientation (Pittino et al., 2018).
Ownerdeath do us

part 
On the topic of succession, Kandade et al. (2020) suggest that psychological ownership, in the form of a high level of trust and early affiliation with the business, influence leadership skills of the next generation, and Sund et al. (2015) conclude that both legal and emotional ownership must be addressed in the preparations of a successful intra-generational succession. Björnberg and Nicholson (2012) coined the term "emotional ownership" to describe the relationship between next-generation family members and the firm. They considered actual ownership and employment in the business to be influential, but neither necessary nor sufficient for the creation and maintenance of emotional ownership. Their study, however, did not consider the spouses of the owner-managers. Rau et al. (2019) studied the relationship between innovation and psychological ownership. They showed that if the third and later generations of owner-managers have high levels of psychological ownership, innovation output is as high as in the founder and second generations. Further research on the roles that non-active family members, grandparents, children and spouses play in supporting or weakening psychological ownership is called for. Psychological ownership may explain why a widow who owned no shares before the death of her husband nevertheless takes on the responsibility and continues the business. By shedding light on widows, our study improves a poorly studied perspective in current literature.

In summary, literature on women in family business succession has treated the dynamics of intra-family succession. In particular, the focus has been on elements that allow planning, for example encouraging and incorporating daughters as successors, and the transfer of social capital, networks and legacy. The sudden and unexpected death of an owner-manager of a family business may upset the best of succession plans. How the widow chooses to act will affect the company, the family, and the future of the business as a family firm. Psychological ownership and the theory of double loss may explain why widows choose not to sell the firms. However, these theories do not tell us about the different roles that the widow must consider in order to satisfy the interests of herself, the family and the business. This has not yet been sufficiently studied, neither in the literature of sudden death or sudden succession, nor in the literature on spouses in family firms (see also Sharma, 2004). MartinezJiménez (2009) called for research into the factors that influence the decisions of widows. We answer this call by exploring the alternative roles taken or considered by the widow in situations when she had no salient role in the family business prior to the death of her husband.

\section{Method}

This study focuses on rare succession events - the sudden death or diagnosis of a fatal illness leading to the premature death of an owner-manager, followed by an unexpected decision by the widow to take over the firm, and her successful execution of this decision. Given the limited previous work on the roles of spouses and widows in family firms, we chose an inductive approach and purposeful sampling of the cases (Eisenhardt, 1989; Patton, 2002, p. 230). The value of such an inductive case study approach in family business research is highlighted by for example De Massis and Kotlar (2014) and Kammerlander and De Massis (2020). We explore the roles a widow considers or takes in a family business when the ownermanager spouse dies. By exploring the roles of the widow, we provide an understanding of why she decides to keep the firm. Hence, our research is interpretative in character (Nordqvist et al., 2009).

\section{Case selection}

Our paper builds on a study of three Swedish cases. Selecting the cases was a challenge since multiple criteria must be met (Charmaz, 2006, p. 100). First, the firm must be a private limited 
company [1]. We decided to focus on this business form, and not on, for example, partnerships, because such firms are intended to outlast the current owners. Further, this form can be used for one-man ownership. Second, the death of the owner-manager must have occurred relatively hastily and unexpectedly, giving the family little possibility to plan ahead. We use the term "sudden succession" for this criterion ( $c f$. Steier, 2001). In two cases, a diagnosis of aggressive cancer brought the family to face the unavoidable, with a few months to prepare. In the third case, myocardial infarction gave the family no time at all to prepare. The sudden succession happened five, ten and 35 years before we met the families. Third, the shares should not be subject to any transfer regulation, such as post-sale purchase clauses in the articles of association or a will with other beneficiary than the spouse. Such regulation would indicate ownership succession planning and hence make the case fall outside the definition of sudden or rushed succession. Fourth, the widows must not have had any major role in the firm prior to the death of the husband. Thus, their skills as business leaders were untested. In one case, the widow had been employed in the firm for several years, but in the other cases her role had been less formalised. The widows had, for example, hosted workers in the family home, hosted dinners, met customers, worked as extra staff during stocktaking, and been a listener at the dinner table. None of the widows had held a managerial position or gained experience of running their own company before taking on the family business. Fifth and lastly, the company must have at least five employees at the time of the sudden death, as we believed that the presence of employees affected the widow's decision whether to take over. The numbers of employees in our firms were between five and 60 .

In total, we identified four cases that met the criteria. Three of them were included in the study. The fourth widow initially agreed to participate in the study, but later declined an interview. It came to our knowledge that she was suffering from a long-term illness and was in need of hospital care.

\section{Case description and context}

It should be noted that when searching for cases we looked for family businesses taken over either by a widow or by a widower. The cases we found were all cases of female successors. The three cases were located in different counties of Sweden and were from different industries. The cases also have some similarities, in that all were of similar size and active in some form of manufacturing industry. The deceased owner-managers were defined as founders and first-generation owners of their businesses, even if one of the companies had a previous history with another family before being bought by the husband in our case. As owner-managers, the late husbands had been actively involved in everyday business, and carried out such tasks as operating machines or tools. For this reason, the hospitalisation of the husband had a great effect on the daily business and on the possibility of urgent succession planning. Even if he could provide to-do lists, he could not transfer important hands-on know-how to the wife. All three couples were married and had more than one child, and all children were adults at the time of the death of their father.

To enable a better understanding of external factors of our cases, there is a need for knowledge about the national context (see e.g. Breton-Miller et al., 2004; Dana and Dana, 2005; Welter, 2011; Mustafa et al., 2019). Families play a central role in the Swedish economy as carriers of capital over time, and family businesses are the dominant form of business in the country. About three-quarters of all companies are family-controlled and they are present in all industries, except the public sector (Sjögren, 2018). The smallest company size (fewer than 50 employees) constitutes the largest share, while the proportions of family businesses among medium-sized and large companies are estimated to be half and one-fifth of all companies, respectively (Bjuggren et al., 2011). Family businesses account for over a third of Swedish employment and Swedish GDP, and the shares have been rising in recent

\section{Owner- manager when death do us part}


decades. In an international perspective, the proportion of family-controlled multinational firms is very high, representing foremost capital-intensive industries and consumer industries. In all three cases, the firms belonged to industries that traditionally have been dominated by male owners and a masculine style of management.

The business system in Sweden is embedded in a welfare economy, characterized by corporatism, high income taxes, equal rights for men and women, consensual democracy and generous social welfare programs. Since the mid-1980s, a number of deregulations have been carried out intended to improve the efficiency of the Swedish economy. Capital markets were deregulated and a series of tax reforms, intended to reduce the large distortions inherent in the earlier tax system, were implemented. These institutional reforms entailed a substantial levelling of the playing field, and many of the hurdles for small family-owned businesses were removed (Bjuggren et al., 2011). The abolition of the inheritance tax and the wealth tax, in particular, made it financially easier for family firms to pursue their succession plans and to keep the ownership within the family (Sund and Bjuggren, 2013). In Sweden, spouses inherit each other, and children will wait until the death of the second parent before they acquire their part of the inheritance. Therefore, the shares in all our cases were inherited by the widow in accordance with Swedish default inheritance law (cf. Carney et al., 2014). Parents are granted testamentary freedom for half of the estate, while the other half is guaranteed to their offspring. Male and female successors have the same rights in inheritance law.

\section{Interviews and supplementing documents}

We conducted in-depth semi-structured interviews with widows and heirs in three cases of unexpected death of an owner-manager. The average duration of an interview was just over $60 \mathrm{~min}$, ranging from $49 \mathrm{~min}$ to almost $1.5 \mathrm{~h}$. In the case in which the death had occurred 35 years ago, the widow had passed way before we could conduct an interview, and we could only interview the daughter, who is the current owner-manager.

\begin{tabular}{lll}
\hline & \multicolumn{2}{c}{ Interviewees } \\
\hline Case 1 & Widow $(62 \mathrm{~min})$ & Daughter and CEO (64 min) \\
Case 2 & n/a & Daughter and CEO (88 min) \\
Case 3 & Widow (61 min) & Son and CEO (49 min) \\
\hline
\end{tabular}

The interviews were conducted in Swedish by both authors present at all times, recorded and transcribed verbatim. We started with open questions such as "Tell us about your late husband, how was he?" (widows) or "Tell us about the time when your father passed away" (children). Later in the interview we put the focus onto specific elements such as the sudden succession, "Did you ever talked about the sensitivity of having a one-man-business, if [the husband] would become sick, hospitalised or even die?", the widow's ownership "You stepped in as the business owner, was that a given for you, or did you discuss alternatives such as sharing ownership with your children?" and regulation "Did you have a matrimonial agreement? Did you husband have a will?".

As often in case studies, the interviews were supplemented by written documents (De Massis and Kotlar, 2014), such as previously published interviews, business life stories provided by the family, and shareholders' agreements. These secondary data were primarily used to contextualise the interviews and to triangulate information that the interviewees answered vaguely. For example, business life stories provided us with detailed information of firm size over time and a copy of a shareholders' agreement confirmed details of the coownership between widow and children. 
A methodological limitation might be the element of backward history, i.e. the risk of being misled when studying events and processes with hindsight (ex post), and being trapped by a narrative produced by the interviewees. Ideally, the stories should be confirmed by contemporary sources, such as the minutes of board meetings. However, according to our interviewees, discussions about the role of the widow as owner-manager were informal and not put into written protocols. Since we were aware of this, we asked source-critical questions during the interviews. In addition, we wrote a chronological history of each case to ensure that we mastered the details.

Finally, our study is limited to three cases, but when interpreting our findings, we make use of our previous historical study of widows from the 17th century onwards (Sjögren, 2021). These historical widows have served as a point of reference for constructing our typology.

\section{Data analysis}

The transcribed interviews and the documents were processed with aid of the NVivo software. To identify themes, the codification process was conducted in two steps. In the first step of the process, quotes that gave voice for the widows' choices, considerations, intentions, feelings and reflections were selected to enable within-case interpretations (Nordqvist et al., 2009). This step was performed by one of the authors, to ensure continuity. In Table 1, we exemplify phrases that triggered this first step of codification. This step was followed by a joint codification process by both authors. In this second step, cross-case analysis, we discussed similarities, differences and nuances of the responses. When grouping the codes into categories we also developed names for the role-types, eventually leading to our findings and the proposed typology (Eisenhardt, 1989). In the findings, each role-type is illustrated by quotes from the interviews to provide transparency.

\section{Findings}

The roles of the widow - a typology

Four main roles taken or considered by the three widows emerged from the data, generating a typology of roles that a widow can choose after the sudden succession. The role she chooses becomes important not only for herself but also for the next generation, both if she decides to keep the business and if she decides to sell/liquidate it. A widow can play more than one role at the same time, and she can switch between roles.

A widow can choose to take on the role of exiteur, where she decides to sell the company or its assets or wind it up. Alternatively, she can act as an understudy for her late husband, and actively run the company as a leader with a mandate to make strategic decisions. If she creates new economic value on the basis of her heritage, she will take the role of entrepreneur.

\begin{tabular}{|c|c|}
\hline Widow & Daughter/son \\
\hline For me it was important. . . & This is her intention... \\
\hline The reason why I ... & For Mum, this is important... \\
\hline This made me go on... & Mom had a strong spirit, she believed she could do it \\
\hline I saw no alternatives & \\
\hline I lacked the experience. . . & This gave her incitements. . . \\
\hline How could I take the role? & This causes anxiety, I'm sure \\
\hline My purpose was to overbridge. . . & She feared... \\
\hline I felt a strong belief. . . & She often felt uncomfortable... \\
\hline I felt acceptance. . . & I can’t imagine Mum. . . \\
\hline It was for the children's sake & We all saw it as a temporary solution \\
\hline
\end{tabular}

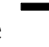


The criterion for being regarded as entrepreneur is that she not only builds on what exists, but also takes the initiative for new products and services, increasing in this way the financial risk and creating innovations that open up new markets. Finally, the widow can choose the role of bridge-builder, where she maintains values that her husband has built up, without necessarily replacing him in management. (This contrasts with the roles of understudy and entrepreneur, who do replace the husband). In the role of bridge-builder, her actions are directly linked to the goal of intra-family succession. As a bridge-builder, the widow functions as the link between her spouse's life's work and the challenges facing the next generation. To a large degree, the role of bridge-builder coincides with the roles of understudy and entrepreneur.

\section{The exiteur}

A widow who decides to sell the business or its assets to someone outside the family or to wind up the company takes the role of an exiteur. In our cases, none of the widows chose this route. However, all of them considered it and shared the reflections they made when making their choice. The exit alternative could have been triggered, they said, by, for example, personal doubt, a bid from a potential buyer or a recommendation from an advisor. The following quotes illustrate these alternative triggers.

None of the widows had prior experience as business leaders or entrepreneurs. Their careers had been in industries very different from that of the family firm. For this reason, it was natural for them to feel doubt about taking on the role as owner-manager.

I think she felt inferior. It must have been hard. She had many doubts. It must have been. . . We don't really speak about emotions in my family. [. . . It was a mental struggle for her. "What is this?" "Am I doing the right thing?” Daughter, Case 2

Widows would also consider taking the exit alternative if advised to do so. Our interviewees mentioned financial or legal advisors who had assumed that selling would be the first choice for the widow, and offered their services to find a buyer, or recommended a business broker. In Case 2, the oldest case, the widow was faced with the assumption that she was willing to sell. The daughter explained that her mother was determined not to be fooled by someone who thought they could get their hands on the business for a bargain price.

And maybe, it was not an attempt to fool her, but there were offers to buy the business. I think they believed that she [the widow] could not handle it. So, she thought "I will show them..." Daughter, Case 2

The widow in this case gained energy and capability from the doubt of others. Taking over the business also became a personal victory - she had been able to take centre stage and amaze the audience.

A final example of an exit trigger is an offer for the company or its assets. Offers could be made by such actors as key employees, competitors, and business connections. All widows in our study received offers. However, none of them accepted such an offer.

For me it was unthinkable to go home and do nothing, just a bag of money if we would sell. Or sit there with arms crossed and look at old photos. For me, it was important to have something to do. Widow, Case 1

Interestingly, the exit choice can be influenced by the former owner-manager after his death. If he has been running the business for a long time, and has created a living organism with an independent raison d'être, it might be hard for his widow to sell. However, plans for a business exit laid down by the deceased owner-manager can affect both the widow and the heirs. The son in Case 3 explained his openness to a future exit: 
I can't see my mother running this together with an external CEO. She says that she and Dad spoke about selling the business in the future, so I think he had an ambition to sell. Son, Case 3

\section{The understudy}

A widow who decides to continue the business in the same direction as her late husband takes the role of an understudy [2]. This role is much influenced by the mentality of "the show must go on". It may be important for many persons, such as the widow herself, the children and other family members, and the employees, that the business continues.

We were very close, while he built this firm. I know what he wanted and what he thought. I think this made me continue. Widow, Case 1

This widow emphasised that she shared her husband's professional network, and this gave her the confidence needed to take on the role, even though she lacked relevant business knowhow. In Case 2, the death of the owner-manager had been preceded by a period in hospital during which he was not able to take care of the business.

Mum had to do something. She asked for leave of absence [from her ordinary job] and tried to run the business daytime and went to the hospital in the evenings and asked, "What do I do now?" and then she went back. So, it was a dialogue with him at the hospital. Daughter, Case 2

The interviews gave clear evidence that the widows had felt a responsibility towards their husbands to ensure continuation. The sense of responsibility did not seem to be connected with ownership of the business. On the contrary, while the company had been owned by the husband, legal default rules on matrimony property gave the wife the right to half the value of the shares. Being close to the business, seeing the way in which her husband strove, and being involved in the endeavour would result in what is known as "psychological ownership" of the business (Pierce et al., 2001). In some circumstances, this feeling of responsibility, or duty, may have been the only reason for keeping the business.

Mum is not so comfortable in the industry. She does it just because Dad had it, because she loved Dad. [... . I think Mum has an intention, and mainly it is just continuation. Daughter, Case 1

Heinonen and Ljunggren (2018) have shown that the sense of responsibility can relate, to various degrees, to the employees. This was reflected in the interviews we conducted.

I felt an obligation towards the staff, I think they needed to know that there were no major changes due to this. Widow, Case 3

I almost went too far pleasing them, to make them stay. I did not request much. I wish I had done more, put up aims, set strategies. Question some things. I did nothing of this. Widow, Case 1

Filling the shoes of her late husband could be experienced as overwhelming and connected with doubt. Our widows confirmed that it was difficult to find a new role, and that it took some time. Support from the children, friends, business partners and employees had been important to them.

How could I cope with is? How can I be as [the husband]? But I realised that I could not be him, I could only be myself. And I got so much love from these people [the employees]. Widow, Case 3

The daughter in Case 2 described the transformation from doubt to confidence when her mother saw that she could run the business without her husband. The customers did not abandon them, and she received help from advisors. This strengthened not only the widow, but also the daughter, who later decided to join her mother and subsequently took over the firm.
Owner-
manager when death do us

part

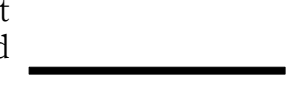

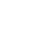


But when Mum started, I understood that a woman can, and that it is possible to run a firm in another way - you don't need to be the craftsman. Daughter, Case 2

\section{The entrepreneur}

In the three cases we studied, none of the widows completely took on the role of a typical entrepreneur, yet elements of this role were present in the way they handled investment and financial risk. We identified three variables that influenced the widow's decisions in this matter. The first variable is willingness to put the business at risk, and the widows did not want to jeopardize the firm. The daughter in Case 2 reflected on her mother's willingness to develop the firm. Investment choices were made with the main objective of avoiding exposing the company to serious risk.

She invested in new machines and developed. She definitely did. But for Mum, it was important with economic stability. [...] That was what she did, and it was tremendously important. She gave it [the firm] the stability needed and proved that this will work with someone else than Dad. Daughter, Case 2

The widow in Case 3 also chose a path of caution when moving along with the company. The son explained the difference in mindset between himself and his mother.

She is more cautious [than me]. Very scared that if ... she sees more risk and maybe enlarges them, as I see it. But it is also for the good. Son, Case 3

The reluctance to take on a high financial risk that jeopardises the company goes well in hand with the double-loss theory (Moussaid et al., 2019). Causing the business to fail may be just as bad as selling it, and undermines the possibility to take any of the other roles, the role of the understudy or the bridge-builder. This may be why the entrepreneurial characteristics of the widows were rather subdued in the cases we studied. However, in Case 1, the widow was willing to take higher risk than her children, and as the sole owner she sometimes supported the business with additional financial means.

What I find positive is that the children are very cautious. They are afraid that we in the end will lose money. And I'm more like this, as my husband said, "You cannot accelerate and brake at the same time". So, if you believe in it, you have to accelerate. And then it will cost you. Widow, Case 1

The second variable we identified is the level of commitment of the children. If the children already hold management positions in the family business, the widow may decide to stand back and let them take on entrepreneurial activities instead. In such cases, she can take a more supportive role as a bridge-builder, rather than the role of an entrepreneur. The widow in Case 1 , who was willing to invest in the business, decided not to take a management position to pursue her entrepreneurial ideas, and instead placed the entrepreneurial opportunities into the hands of her daughter. In Case 2, the widow was economically cautious. She reasoned that, although her choice inhibited the development of the business, she was consolidating the company, which would later make it possible for her daughter to undertake entrepreneurial actions.

For her, profitability was important [ . . . ] and that money I had great use of when I wanted to develop or when I started to say, "Now we have to invest!" Daughter, Case 2

The third variable, which may be the most obvious one, is the age of the widow. It may be necessary for a widow who takes the role of entrepreneur to hold on to the shares for some time after becoming a widow, and during this period to grow into the role of an ownermanager. All three widows in our study decided to keep the shares for longer than a transition period - a period that may end by her selling the shares (in the role of exiteur), or passing on 
ownership to the next generation (in the role of bridge-builder). The role of entrepreneur is the most active role in our typology, and a widow who takes this role will embark on a new career path. Depending on the stage in life and age at which she becomes a widow, she might hesitate to pursue a new career. In the cases presented here, all widows had had other careers prior to the death of their husband. The widow in Case 3 was 61 years old when her husband passed away. She said:

I was not at an age to initiate something new and start working again. Widow, Case 3

\section{The bridge-builder}

The choice not to sell is closely related to a desire to pass the business on to the next generation. All interviewees were asked directly whether their/their mother's decision would have been the same if she did not have children. The answer was clear in Cases 1 and 3: the widows acted with an expressed ambition to enable succession to the next generation.

Because I felt that I cannot stay in this post, it was primarily to help bridge this. . . because I felt I lacked the knowledge to run it. Widow, Case 1

If I did not have children on my own? [. . . Y Yes, yes, I think I would have sold. I think so. [. . .] You mean that I would have stepped in as CEO? No, I would not have done that. Widow, Case 3

The sole goal of a bridge-builder may be to enable the younger generation to take over the family business. Even if all the shares are in the hands of the widow, she may let the children run the business without her interference, and may see it as her role to avoid conflicts either between herself and the children, or among the children.

Some things I just do not need to comment and confront. We know what the future will bring. I do not need to yap on about it. Widow, Case 1

A widow may act to protect the children from hard business decisions by holding on to the shares and the economic risk, while they learn to run the business. Further, she may choose to take tough decisions herself, with the justification that it is better for the children to be angry with their parent, than each other.

I want to protect them from some discussions. Because it is easier for me as a single owner to invest more money into this. It is that simple. I will try to avoid as many conflict areas as possible. Because keeping the family together is most important. Then. . . it will work out in the future. Widow, Case 1

I think she was afraid to let go of the shares [to the children] . . . I think by holding on to the shares, her role was to keep the family together. Son, Case 3

The widow in Case 3 believed that her ownership of the business could bring the family members closer together. She referred to another family business, in which the third generation had decided to sell, and the cousins never met each other anymore. Owning a business brought them together, she claimed, as if they were acting in the same theatre play.

The owner-manager in Case 1 expressed on his deathbed strong confidence that his daughter, who had stepped in as member of the board when he had been hospitalized, would manage the business well. However, he still wanted his wife to be the sole owner of the business, to keep the business and the family together.

Even if a widow intends to take the role of bridge-builder, she can choose another role at the time of the death. For example, if the children are too young to be involved in the business, or are otherwise not ready to take on managerial roles, she take the role of understudy for a period. It is both possible and probable that a widow moves between the roles, and her position in the typology is dynamic, rather than stationary. 


\section{JFBM}

\section{A dynamic view of the roles}

The typology of the roles a widow may take has been constructed based on the roles that the widows in our case study considered and adopted. The borders between the roles are not strict. A widow can play more than one role at the same time, and she can switch between roles. Figure 1 presents the dynamics of the typology. The urgency of a sudden or unexpected death would normally lead the widow to an immediate choice either to sell or step in, in the role of either exiteur or understudy. A widow may take any of the four roles after the acute phase. The choice to sell or liquidate (exiteur), and the choice to pass on to the next generation (bridge-builder) remain open for some time, indicated by the outstretched ellipses in Figure 1. Further, a widow who takes the role of entrepreneur must previously have acted as understudy, as indicated by the time sequence of these two ellipses.

The widows in Case 1 and Case 3 mainly took the role of bridge-builder. This choice was influenced in both cases by the age at which she became a widow and the fact that one child was already active in the business at the time of the unexpected death. In Case 3, the son had already become a member of the management team and started to develop his role as an entrepreneur. This allowed the widow to choose the role of bridge-builder at an early stage. In Case 1, the daughter had acted as the understudy of her father, which enabled the widow to operate as an owner, not an owner-manager. In contrast, the widow in Case 2 was clearly an understudy of her husband, both during the phase of acute illness and after the death. It could be expected that when the daughter entered the business several years later, the widow would take on a mainly bridge-builder role. However, the widow remained as an understudy until she left all managerial tasks to her daughter, and remained an owner until her death.

\section{Discussion}

The theory of psychological ownership explains well why widows may decide to continue the family business even if they have held no salient role in it prior to the death of their husband (Pierce et al., 2001). Widows who take the role of understudy illustrate this most clearly. It does not matter that the widows have not had a previous managerial position, nor is ownership important. There are four possible statuses for her ownership of the business. First, she could hold shares in the firm prior the sudden death, and thus be a co-owner. Second, she could own no shares but be entitled to half of the value of the shares in the case of divorce, depending on the national legal rules on matrimony property. Third, she could own no shares and have no right to the value of them as a consequence of a marriage settlement

Figure 1.

Dynamics of the roles of a widow

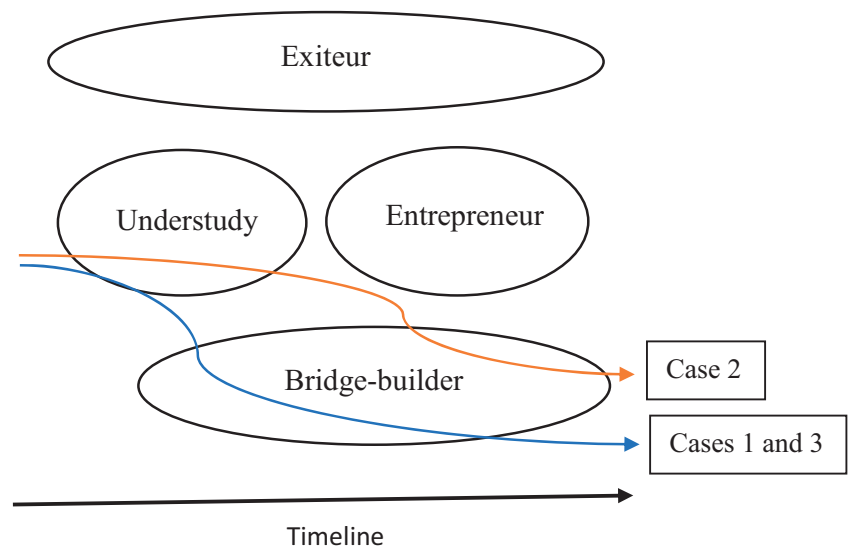


(or similar) between the spouses. Finally, she may or may not inherit the shares, which again depends on the national legal framework and on any marriage settlement between the spouses or will made by the husband. In contrast, psychological ownership may be the result of investing time and intellectual energy into her husband's business, through such activities as hosting dinners, acting as extra personnel, being a listener and planning the family life around the demands of the business. She may also feel ownership as a result of being familiar with the business and its employees, suppliers or customers, and by feeling associated with it (Pierce et al., 2001). Previous family business studies using psychological ownership as their theoretical framework have focused on family and non-family members active in the business (see, e.g. Sieger et al., 2011; Bernhard and O'Driscoll, 2011; Huybrechts et al., 2013; Ramos et al., 2014; Henssen et al., 2014; Broekaert et al., 2018; Lee et al., 2019). This study shows that the framework could be equally relevant for family members who are neither active in the business, nor legal owners of the same.

The double-loss theory explains why widows hesitate when they consider the role of exiteur, which is in line with previous research on widows by Moussaid et al. (2019) However, exiting might not necessarily be considered a loss, especially if the late husband had considered exit alternatives before he died. A double loss may be more evident if a widow chooses to continue and then sees the business fail. This situation is experienced strongly as a loss both by the widow and her children. The fear of failing affects the willingness to take risks, and may explain why widows do not choose the role of entrepreneur. Hence, our findings show that the double-loss theory explains not only why widows may be reluctant to take the role of exiteur, but also the degree to which they are willing to take risks as understudy, bridge-builder or entrepreneur. Our results indicate that the widows' reluctance to take the role as entrepreneur may come from an unwillingness to take financial risk explained by the double-loss theory.

Psychological ownership and the double-loss theory may explain why widows choose not to sell the firm. However, these theories do not explain other roles that widows may take. Once a widow has decided to keep the family business, she enters the next stage of uncertainty. She searches for a role that satisfies the interests of herself, the family, and the business. We identify underlying dimensions of her choice of role. Figure 2 shows how her choice must be positioned along the family versus business dimension, and along the self-fulfilment $v$ s. collective fulfilment dimension.

A widow who takes the role of exiteur expresses self-fulfilment. For example, the money received as payment for the company's shares or its assets can be invested to ensure a comfortable standard of life or elderhood. The money can also be used for the widow's own entrepreneurial activity, separate from that of her late husband. The term "self-fulfilment" should not be interpreted as indulging in egocentric purposes. On the contrary, the widow can choose an exit role that contributes to her self-fulfilment, while at the same time benefiting others. By selling the business, she can, for example, pay for her children's education or

\begin{tabular}{l|r|r|} 
& Family orientation & Business orientation \\
\hline Self-fulfilment & Exiteur & Entrepreneur \\
\hline Collective fulfilment & Bridge-builder & Understudy \\
& &
\end{tabular}

Figure 2. Dimensions of the roles of a widow 
provide start-up capital for their business ideas. She can also use the wealth for philanthropical actions, such as starting a foundation in her own, her husband's, or the family's name. Self-fulfilment may also come from the role of entrepreneur. In this role, she pursues a new career and explores her skills as a business leader.

In contrast, a widow who takes the role of bridge-builder or understudy puts the group's interests before her own, and supports what we call "collective fulfilment". As a bridgebuilder, the widow's main ambition is to pass on the business to the next generation. This gives her a reason to stay out of management, and focus on the role of owner. She may leave the children to run the business essentially without her interference, while she bears the economic risk. The "collective" may be the children or the extended family, with in-laws, grandchildren, etc. Other stakeholders constitute the collective of a widow who takes the role of understudy. In this case, the employees are often most prominent in the mind of the widow. It is also important to state clearly to suppliers, customers, and collaborative partners that the business will continue in the family's name.

The two roles of understudy and entrepreneur focus on business. This may be the result of viewing the company as a living organ itself, with an independent raison d'etre. The entrepreneur sees that the business has a potential to grow and be developed. The understudy sees other individuals who engage with the firm or benefit from its activities, such as employees, suppliers, and customers. In contrast, the roles of exiteur and bridgebuilder focus on the family. The widow will receive funds to invest in the family's future when she sells the company or its assets. The business can continue, in one form or another, with new owners. However, if the firm is liquidated, this will affect not only the family but also the business, as shown by the dotted line in Figure 2. Finally, a widow who takes the role of bridge-builder ensures succession within the family, which reflects her choice to focus on the family.

\section{Contributions and further research}

We have explored the roles that a widow may take following the sudden and premature death of her owner-manager spouse, when she had played no salient role in the business prior to the death. We contribute to the literature on sudden successions and women in family firms by examining a hitherto understudied group, i.e. widows. By studying widows who have successfully taken over the business, we can learn more about how to overcome sudden succession as a preventing factor for intra-family succession (De Massis et al., 2008). Succession planning should ideally include unexpected events such as divorce, long-term illness and death. Despite the lack of such emergency plans, the widows in our cases did not only ensured that the business survived the loss of the previous owner-manager, but also managed to include and engage the next generation.

We construct a typology of four main roles and analyse the underlying dimensions that these role-types represent. This contribution to literature can be utilised as a tool for further research on, for example, widow leadership and widow entrepreneurship identity. The underlying dimensions can be used to explore how support from, for example, employees or other family members influences the widow's role identity and social identity (see, e.g. Burke and Stets, 2009).

Our study is explorative and builds on the experience of a limited number of cases. With access to more data, the typology could be tested and become the subject of generalisation. Further, in all three cases the widow had children who either already were active in the business or later became active. The presence of children was not a prerequisite when selecting the cases. However, when analysing our findings, we saw that the existence of children was an important factor for the roles taken or considered by the widow. This should be kept in mind when reading the typology. Further studies should ideally include widows of 
different ages and compare widows with or without (joint) children, as well as those with underaged or adult children.

The study may also contribute to practice. Our typology can assist formal and informal advisors who meet widows or widowers of family business owner-managers. It can be used as a tool for an open and non-prejudiced discussion of her/his ambitions and goals at a time when she/he might not be able to verbalise them. Advisors may be important for the choices made by widows whether to take over the business. Some advisors support the widow in this decision, while others take it for granted - often against the will of the widow - that the family or widow will give up the business. Given that sudden deaths are fortunately a rare reason for family business succession, tools that help advisors and family business owners to navigate among the choices will be useful. Further studies that elaborate on the role of advisors will be welcome. Additionally, the role of the board of directors in sudden or rushed successions in private family businesses remains unexplored (while their role in public companies has been studied by Nguyen and Nielsen, 2010; Borokhovich et al., 2006). Family dynamics, such as sudden death, divorce, severe injury or other family crises, may impair the abilities of an owner-manager. The actions taken by the chairman of the board, or other board members, may compensate for such an impairment, which calls for further investigation.

\section{Notes}

1. After the U.K. model, Sweden has one business form limited by shares, but two types of the same; the private and the public company.

2. The term understudy is used in theatre vocabulary for a person who steps in if an actor or actress is unable to appear on stage because of illness, injury, emergency or death.

Earlier versions of this paper have been presented at the CeFEO Writing Workshop in December 2020 and the EHFF seminar at Stockholm School of Economic in January 2021. Thanks to the organizers and participants and in particular, many thanks to Professor Philipp Sieger, Professor Ethel Brundin and Assistant professor Kajsa Haag who have given us important and thoughtful comments on our manuscript.

\section{References}

Achtenhagen, L., Haag, K. and Welter, F. (2017), "The role of gender in family-business research: a systematic review of the literature", in Ratten, V., Dana, L.-P. and Ramadani, V. (Eds), Women Entrepreneurship in Family Business, Routledge, New York, pp. 16-45.

Ahrens, J.-P., Landmann, A. and Woywode, M. (2015), "Gender preferences in the CEO successions of family firms: family characteristics and human capital of the successor", Journal of Family Business Strategy, Vol. 6 No. 2, pp. 86-103.

Antheaume, N. and Robic, P. (2012), From Wife to Widow Entrepreneur in French Family Businesses. An Invisible-Visible Role in Passing on the Business to the Next Generation, Université des Nantes, Lemna.

Barbera, F., Stamm, I. and DeWitt, R.-L. (2018), "The development of an entrepreneurial legacy: exploring the role of anticipated futures in transgenerational entrepreneurship", Family Business Review, Vol. 31 No. 3, pp. 352-378.

Bernhard, F. and O'Driscoll, M.P. (2011), "Psychological ownership in small family-owned businesses: leadership style and nonfamily-employees' work attitudes and behaviors", Group and Organization Management, Vol. 36 No. 3, pp. 345-384.

Björnberg, A. and Nicholson, N. (2012), "Emotional ownership: the next generation's relationship with the family firm”, Family Business Review, Vol. 25 No. 4, pp. 374-390.

Bjuggren, C.M., Johansson, D. and Sjögren, H. (2011), "A note on employment and GDP in Swedish family-owned businesses: a descriptive analysis", Family Business Review, Vol. 24 No. 4, pp. 362-371. 
Borokhovich, K., Brunarski, K., Donahue, M. and Harman, Y. (2006), "The importance of board quality in the event of a CEO death", The Financial Review, Vol. 41 No. 3, pp. 307-337.

Breton-Miller, L.L., Miller, D. and Steier, L.P. (2004), "Toward an integrative model of effective FOB succession”, Entrepreneurship Theory and Practice, Vol. 28 No. 4, pp. 305-328.

Broekaert, W., Henssen, B., Lambrecht, J., Debackere, K. and Andries, P. (2018), "Limits to psychological ownership in the family business", Journal of Family Business Management, Vol. 8 No. 2, pp. 196-216.

Burke, P.J. and Stets, J.E. (2009), Identity Theory, Oxford University Press, Oxford.

Campopiano, G., De Massis, A., Rinaldi, F. and Sciascia, S. (2017), "Women's involvement in family firms: progress and challenges for future research", Journal of Family Business Strategy, Vol. 8 No. 4, pp. 200-212.

Carney, M., Gedajlovic, E. and Strike, V.M. (2014), "Dead money: inheritance law and the longevity of family firms", Entrepreneurship Theory and Practice, Vol. 38 No. 6, pp. 1261-1283.

Cesaroni, F. and Sentuti, A. (2014), "Women and family businesses. When women are left only minor roles", The History of the Family, Vol. 19 No. 3, pp. 358-379.

Charmaz, K. (2006), Constructing Grounded Theory: A Practical Guide through Qualitative Analysis, Sage, London.

Colli, A. (2003), The History of Family Business, Cambridge University Press, Cambridge.

Combs, J.G., Shanine, K.K., Burrows, S., Allen, J.S. and Pounds, T.W. (2020), "What do we know about business families? Setting the stage for leveraging family science theories", Family Business Review, Vol. 33 No. 1, pp. 38-63.

Dana, L.P. and Dana, T.E. (2005), "Expanding the scope of methodologies used in entrepreneurship research", International Journal of Entrepreneurship and Small Business, Vol. 2 No. 1, pp. 79-88.

De Massis, A. and Kotlar, J. (2014), "The case study method in family business research: guidelines for qualitative scholarship", Journal of Family Business Strategy, Vol. 5 No. 1, pp. 15-29.

De Massis, A., Chua, J. and Chrisman, J. (2008), "Factors preventing intra-family succession", Family Business Review, Vol. 21 No. 2, pp. 183-199.

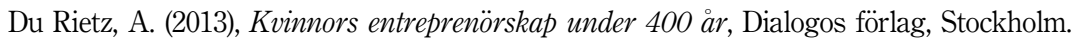

Eddleston, K.A., Kellermanns, F.W. and Collier, G. (2019), "Research on family firm innovation: what do family firms actually think and do?", Journal of Family Business Strategy, Vol. 10 No. 4, p. 100308.

Eisenhardt, K.M. (1989), "Building theories from case study research", Academy of Management Review, Vol. 14 No. 4, pp. 532-550.

Erdem, F. and Atsan, N. (2015), "Trust based relationships between family members and long-term employees of family owned SMEs”, International Business Research, Vol. 8 No. 4, pp. 223-232.

Fitzgerald, M.A. and Muske, G. (2002), "Copreneurs: an exploration and comparison to other family businesses”, Family Business Review, Vol. 15 No. 1, pp. 1-16.

Haag, K. (2012), Rethinking Family Business Succession. From a Problem to Solve to an Ongoing Practice, Doctoral dissertation, Jönköping University, Jönköping.

Heinonen, J. and Ljunggren, E. (2018), "He suddenly died. Unplanned succession in family firms", in Heinonen, J. and Vainio-Korhonen, K. (Eds), Women in Business Families. From Past to Present, Routledge, New York, pp. 218-236.

Henssen, B., Voordeckers, W., Lambrechts, F. and Koiranen, M. (2014), "The CEO autonomystewardship behavior relationship in family firms: the mediating role of psychological ownership", Journal of Family Business Strategy, Vol. 5 No. 3, pp. 312-322.

Humphreys, M. (2013), "Daughter succession: a predominance of human issues", Journal of Family Business Management, Vol. 3 No. 1, pp. 24-44. 
Huybrechts, J., Voordeckers, W. and Lybaert, N. (2013), "Entrepreneurial risk taking of private family firms: the influence of a nonfamily CEO and the moderating effect of CEO tenure", Family Business Review, Vol. 26 No. 2, pp. 161-179.

Jaskiewicz, P. and Dyer, W.G. (2017), "Addressing the elephant in the room: disentangling family heterogeneity to advance family business research", Family Business Review, Vol. 30 No. 2, pp. 111-118.

Johnson, B., Magee, R., Nagarajan, N. and Newman, H. (1985), “An analysis of the stock price reaction to sudden executive deaths: implications for the managerial labor market", Journal of Accounting and Economics, Vol. 7 Nos 1-3, pp. 151-174.

Kammerlander, N. and De Massis, A. (2020), "Frequently asked questions in qualitative family business research and some guidelines to avoid risky paths", in De Massis, A. and Kammerlander, N. (Eds), Handbook of Qualitative Research Methods for Family Business, Edward Elgar Publishing, Cheltenham, pp. 1-23.

Kandade, K., Samara, G., Parada, M.J. and Dawson, A. (2020), "From family successors to successful business leaders: a qualitative study of how high-quality relationships develop in family businesses", Journal of Family Business Strategy, in press, available online 12 March 2020, 100334.

Karlsson, J. (2020), Essays on Family Firms and Firm Growth Barriers, Doctoral dissertation, Örebro University School of Business, Örebro.

Laffranchini, G. and Hoy, F. (2020), "The evolution of case study methodology in the study of family enterprises", in De Massis, A. and Kammerlander, N. (Eds), Handbook of Qualitative Research Methods for Family Business, Edward Elgar Publishing, Cheltenham, pp. 125-160.

Larcker, D.F. and Tayan, B. (2012), Sudden Death of a CEO: Are Companies Prepared when Lightning Strikes?, Stanford Closer Look Series.

Lee, K., Makri, M. and Scandura, T. (2019), "The effect of psychological ownership on corporate entrepreneurship: comparisons between family and non-family top management team members", Family Business Review, Vol. 32 No. 1, pp. 10-30.

Litz, R., Pearson, A. and Litchfield, S. (2012), "Charting the future of family business research: perspectives from the field", Family Business Review, Vol. 25 No. 1, pp. 16-32.

Martinez-Jiménez, R. (2009), "Research on women in family firms - current status and future directions", Family Business Review, Vol. 22 No. 1, pp. 53-64.

Martin, L., Jerrard, B. and Wright, L. (2019), "Identity work in female-led creative businesses”, Gender, Work and Organization, Vol. 27 No. 3, pp. 310-326.

Moring, B. and Wall, R. (2017), Widows in European Economy and Society 1600 - 1920, The Boydell Press, Woodbridge.

Moussaid, G., Hussein, T. and Akil, H. (2019), "The challenge in pain: the delayed bereavement at the origin of the act of entry into business of the widow", International Business Research, Vol. 12 No. 6, pp. 99-105.

Mustafa, M., Elliot, C. and Zhou, L. (2019), "Succession in Chinese family-SMEs: a gendered analysis of successor learning and development", Human Resource Development International, Vol. 22 No. 5, pp. 504-525.

Mustafa, M., Ramos, H.M. and Zainal Badri, S.K. (2020), "Determining nonfamily employees' job satisfaction and turnover intentions: the roles of job autonomy and work passion", Journal of Family Business Management, ahead-of-print.

Nguyen, B.D. and Nielsen, K.M. (2010), "The value of independent directors: evidence from sudden deaths", Journal of Financial Economics, Vol. 98 No. 3, pp. 550-567.

Nordqvist, M., Hall, A. and Melin, L. (2009), "Qualitative research on family businesses: the relevance and usefulness of the interpretive approach", Journal of Management and Organization, Vol. 15 No. 3, pp. 294-308. 
Overbeke, K.K., Bilimoria, D. and Perelli, S. (2013), "The dearth of daughter successors in family businesses: gendered norms, blindness to possibility, and invisibility", Journal of Family Business Strategy, Vol. 4 No. 3, pp. 201-212.

Overbeke, K.K., Bilimoria, D. and Somers, T. (2015), "Shared vision between fathers and daughters in family businesses: the determining factor that transforms daughters into successors", Frontiers in Psychology, Vol. 6, p. 625.

Patton, M.Q. (2002), Qualitative Research and Evaluation Methods, Sage, Thousand Oaks.

Pierce, J.L., Kostova, T. and Dirks, K.T. (2001), "Towards a theory of psychological ownership in organizations", Academy of Management Review, Vol. 26 No. 2, pp. 298-310.

Pittino, D., Martínez, A.B., Chirico, F. and Galván, R.S. (2018), "Psychological ownership, knowledge sharing and entrepreneurial orientation in family firms: the moderating role of governance heterogeneity", Journal of Business Research, Vol. 84, pp. 312-326.

Ponthieu, L.D. and Caudill, H.L. (1993), "Who's the boss? Responsibility and decision making in copreneurial ventures", Family Business Review, Vol. 7 No. 1, pp. 3-17.

Poza, E.J. and Messer, T. (2001), "Spousal leadership and continuity in the family firm", Family Business Review, Vol. 14 No. 1, pp. 25-36.

Ramadani, V., Dana, L.P., Ratten, V., Sadiku-Dushi, N. and Welsh, D.H.B. (2017), "Decision-making challenges of women entrepreneurs in the family business succession process", Journal of Enterprising Culture, Vol. 25 No. 4, pp. 411-439.

Ramos, M., Man, T., Mustafa, M. and Ng, Z.Z. (2014), "Psychological ownership in small family firms: family and non-family employees' work attitudes and behaviours", Journal of Family Business Strategy, Vol. 5 No. 3, pp. 300-311.

Rau, S.B., Werner, A. and Schell, S. (2019), "Psychological ownership as a driving factor of innovation in older family firms", Journal of Family Business Strategy, Vol. 10 No. 4, p. 100246.

Rinaldi, A. and Tagliazucchi, G. (2019), "Women entrepreneurs in Italy: a prosopographic study", Business History, Published digitally 29 July 2019.

Salas, J.M. (2010), "Entrenchment, governance, and the stock price reaction to sudden executive deaths", Journal of Banking and Finance, Vol. 34 No. 3, pp. 656-666.

Sharma, P. (2004), "An overview of the field of family business studies: current status and directions for the future", Family Business Review, Vol. 17 No. 1, pp. 1-36.

Sieger, P., Bernhard, F. and Frey, U. (2011), "Affective commitment and job satisfaction among nonfamily employees: investigating the roles of justice perceptions and psychological ownership", Journal of Family Business Strategy, Vol. 2 No. 2, pp. 78-89.

Sjögren, H. (2018), Family Dynasties. The Evolution of Global Business in Scandinavia, Routledge, New York.

Sjögren, H. (2021), Änkor med makt, Dialogos, Stockholm.

Steier, L. (2001), "Next-generation entrepreneurs and succession: an exploratory study of modes and means of managing social capital”, Family Business Review, Vol. 14 No. 3, pp. 259-276.

Sund, L.-G. and Bjuggren, P.-O. (2013), "No gift and inheritance tax: no problems left for succession of family-owned businesses?", European Business Law Review, Vol. 24 No. 1, pp. 149-159.

Sund, L.-G., Almlöf, H. and Haag, K. (2010), "Divorce and death in the family firm - a business law perspective", European Business Law Review, Vol. 21 No. 2, pp. 101-118.

Sund, L.-G., Melin, L. and Haag, K. (2015), "Intergenerational ownership succession: shifting the focus from outcome measurements to preparatory requirements", Journal of Family Business Strategy, Vol. 6 No. 3, pp. 166-177.

Welter, F. (2011), "Contextualizing entrepreneurship - conceptual challenges and ways forward", Entrepreneurship Theory and Practice, Vol. 35 No. 1, pp. 165-184. 
Worrell, D.L. and Davidson, W.N. III (1987), "The effect of CEO succession on stockholder wealth in large firms following the death of the predecessor", Journal of Management, Vol. 3 No. 3, pp. 509-515.

Ownermanager when death do us

\section{Corresponding author}

Hanna Almlöf can be contacted at: hanna.almlof@liu.se 